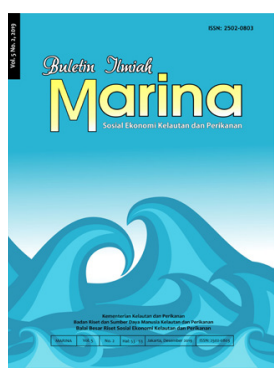

BULETIN ILMIAH MARINA

SOSIAL EKONOMI KELAUTAN DAN PERIKANAN

http://ejournal-balitbang.kkp.go.id/index.php/mra

p-ISSN: 2502-0803

e-ISSN: 2541-2930

Nomor Akreditasi: 10/E/KPT/2019

\title{
MASYARAKAT PESISIR DAN PERILAKUNYA TERHADAP JARINGAN \\ USAHA PERIKANAN: Studi Kasus Daerah Perbatasan \\ di Kabupaten Nunukan
}

\section{Coastal Community and Its Behavior to Fisheries Business Networks: Case Study of Border Area in Nunukan Regency}

\author{
*Nensyana Shafitri, Armen Zulham, dan Umi Muawanah \\ Balai Besar Riset Sosial Ekonomi Kelautan dan Perikanan \\ Gedung BRSDM KP I Lt. 4 \\ Jalan Pasir Putih Nomor 1 Ancol Timur, Jakarta Utara, Indonesia \\ Telp: (021) 64711583 Fax: 64700924
}

Diterima tanggal: 19 Februari 2020 Diterima setelah perbaikan: 3 Juni 2020

Disetujui terbit: 26 Juni 2020

\begin{abstract}
ABSTRAK
Masyarakat pesisir di perbatasan Kabupaten Nunukan (Provinsi Kalimantan Utara, Indonesia) dan Tawau (Sabah, Malaysia) saling ketergantungan diantara keduanya dalam pemenuhan kebutuhan pokok dan input produksi perikanan. Kajian ini bertujuan menggambarkan hubungan kekerabatan masyarakat Nunukan dengan masyarakat Tawau, dan menganalisis perilaku para pelaku utama pada usaha perikanan. Responden dipilih secara purposive terhadap pemilik usaha penangkapan ikan dan budi daya rumput laut di Pulau Nunukan dan Pulau Sebatik. Data primer diperoleh melalui wawancara, Focus Group Discussion (FGD), dan observasi dengan metode survei. Analisis data dilakukan secara deskriptif kualitatif dan deskripsi tabulasi silang dengan penghitungan sederhana. Hasil penelitian menunjukkan bahwa perekonomian masyarakat perbatasan di Nunukan dipengaruhi oleh sistem kekerabatan dalam menjalankan usaha dan perilaku bisnis. Sistem kekerabatan dibangun untuk menjamin agar usaha yang dijalankan dapat berjalan dengan baik. Perilaku bisnis nelayan dan pembudi daya rumput laut menjamin keberlanjutan peningkatan skala usaha melalui akses sumber daya yang terjamin, pemilihan tenaga kerja yang tepat, pemilihan akses pasar yang sesuai, pemilihan teknologi yang tepat, pemanfaatan sumber modal yang saling menguntungkan, serta pemanfaatan sumber tabungan yang ada. Oleh karena itu, pemerintah daerah Kabupaten Nunukan diharapkan dapat membentuk asosiasi atau kelompok dagang dan mendorong lembaga keuangan finansial (terutama Bank BRI atau Bank BUMN lain) mempunyai perwakilan di desa-desa produsen rumput laut dan penangkapan ikan.
\end{abstract}

Kata Kunci: perilaku; kawasan perbatasan; jaringan sosial; perikanan; Kabupaten Nunukan

\section{ABSTRACT}

Coastal communities in Nunukan Regency (North Kalimantan Province, Indonesia) and Tawau (Sabah, Malaysia) are interdependent in the fullfillment of the basic needs and fishery's input production. This study aimed to describe the relationship between Nunukan and Tawau coastal community and to analyze the behaviors of the main actors of fishery businesses. Respondents were purposively selected from the owners of fishing boats and seaweed farm in Nunukan and Sebatik Island. Primary data were collected through interviews, group discussion, and survey observation. Data were analyzed with qualitative descriptive method and cross-tabulation with simple calculation. The results found that the economy of community in Nunukan was influenced by relationship system in business activities and behavior. Relationship system was built to ensure the benefit of their businesses. The business behaviors helped to ensure the sustainability and expansion of their businesses through the guarantee of 
resource access, employee selection, market selection, technology selection, mutual benefit of financial capital sources, and the use of existing savings. Therefore, the government of Nunukan Regency need to establish trade association or groups and to encourage the financial institution (especially government banks) to operate in the village of seaweed and fishing activities.

Keywords: behavior; border area; social network; fisheries; Nunukan Regency

\section{PENDAHULUAN}

Kawasan perbatasan merupakan bagian dari wilayah negara yang terletak pada sisi dalam sepanjang batas wilayah Indonesia dengan negara lain, dengan wilayah darat berada di kecamatan. Pengertian tersebut berdasarkan Undang Undang Republik Indonesia Nomor 43 Tahun 2008 tentang Wilayah Negara, yang esensinya bahwa pembangunan wilayah perbatasan menjadi bagian dari pembangunan nasional. Prasojo (2013) dan Sudiar (2015) menyatakan perbatasan negara menjadi wilayah strategis sebagai pintu masuk pihak luar yang mempunyai kepentingan di Indonesia dan perbatasan identik dengan kawasan tertinggal dari berbagai aspek pembangunan.

Salah satu wilayah yang berbatasan dengan negara lain adalah Kabupaten Nunukan. Pulau Sebatik yang termasuk dalam Kabupaten Nunukan merupakan wilayah yang memiliki perbatasan darat dengan Tawau negara bagian Sabah Malaysia. Kondisi ketimpangan pembangunan terlihat antara Nunukan dengan Tawau. Menurut BPKP2DT (2012) dalam Putra (2015) dan Sudiar (2015), permasalahan yang sering terjadi pada daerah perbatasan di antaranya adalah tingkat kesejahteraan rendah, minimnya infrastruktur, seperti jalan, minimnya sarana dasar permukiman dan akses pusat pelayanan publik, pendidikan, dan kesehatan, serta pengelolaan sumber daya alam. Ketimpangan pembangunan antara Tawau dan Kabupaten Nunukan telah menimbulkan ketergantungan masyarakat di Kabupaten Nunukan dan khususnya Pulau Sebatik dengan Tawau (Setiawan, Bandiyono, Sudiyono, \& Soekarni, 2011; Saleh, 2015; Sudiar, 2015; dan Kurnia, 2018). Ketergantungan ekonomi menjadikan produk kebutuhan pokok masyarakat Kabupaten Nunukan khususnya Pulau Sebatik didominasi oleh produk Malaysia, seperti gas, beras, gula, daging, minuman, dan makanan Selain kebutuhan sehari-hari, kebutuhan usaha petani, nelayan, dan pembudi daya ikan juga bergantung dari Malaysia, seperti pupuk, bahan bakar minyak, es, alat tangkap ikan, dan alat budi daya ikan (Saleh, 2015).
Di sisi lain, Tawau juga mempunyai ketergantungan terhadap Kabupaten Nunukan pada sektor kelautan dan perikanan. Tawau menggantungkan kebutuhan produk perikanan dari Kabupaten Nunukan dan sekitarnya, seperti dari Tarakan. Kondisi tersebut di atas, membentuk jaringan antara masyarakat Kabupaten Nunukan dengan masyarakat Tawau (Sabah, Malaysia). Relasi yang kuat salah satunya disebabkan faktor kekerabatan dan etnis. Jaringan yang terjalin antara masyarakat Kabupaten Nunukan dan Kota Tawau tidak hanya dalam hubungan ekonomi atau bisnis, tetapi juga berkaitan dengan dimensi agama, sosial, budaya, dan politik (Rudiatin, 2018).

Dimensi budaya menjadi cara adaptasi yang mengacu pada perilaku individu, masyarakat, dan lingkungan untuk menghadapi perubahan (Nurisnaeny, 2016). Salah satunya perilaku pelaku usaha sektor kelautan dan perikanan di perbatasan Nunukan, yaitu adaptasi untuk mempertahankan keseimbangan jaringan usaha perikanan. Tujuan dari tulisan ini adalah menggambarkan hubungan kekerabatan masyarakat perbatasan dan menganalisis perilaku masyarakat pesisir di perbatasan Nunukan - Tawau dalam menjaga keberlangsungan usaha perikanan yang terkait dengan akses sumber daya perikanan, pemilihan tenaga kerja, akses pasar perikanan, akses terhadap teknologi perikanan, akses permodalan, dan literasi keuangan.

Kabupaten Nunukan menjadi lokasi kajian mewakili wilayah yang berbatasan langsung dengan negara tetangga, yaitu Malaysia. Kajian dilakukan pada bulan April sampai dengan Oktober 2018. Pengambilan data nelayan dilakukan di Pulau Sebatik pada Kecamatan Sebatik Barat, Kecamatan Sebatik Tengah, Kecamatan Sebatik Timur, dan Kecamatan Sebatik Utara. Wilayah yang menjadi lokasi pengambilan data pembudi daya rumput laut adalah Pulau Nunukan di Kecamatan Nunukan Selatan dan Kecamatan Nunukan. Kecamatan - kecamatan tersebut merupakan wilayah yang mempunyai potensi sumber daya budi daya rumput laut dan perikanan tangkap. Responden dalam kajian ini dipilih secara purposive sampling, yaitu pemilik usaha perikanan, 113 
nelayan, dan 79 pembudi daya rumput laut. Data primer diperoleh melalui wawancara mendalam serta menggunakan kuesioner terstruktur, Focus Group Discussion (FGD), dan observasi. Pengumpulan data dilakukan dengan metode survei. Data primer yang diambil adalah perilaku responden dalam pemanfaatan sumber daya, seperti akses terhadap potensi perikanan, tenaga kerja, pasar, teknologi, modal, dan tabungan. Analisis data secara deskriptif kualitatif dan deskripsi dari tabulasi silang dengan perhitungan sederhana.

\section{KEKERABATAN MASYARAKAT KABUPATEN NUNUKAN DENGAN TAWAU}

Interaksi antara masyarakat perbatasan Nunukan dan Tawau sudah terjalin sejak lama, salah satunya karena adanya ikatan kekerabatan dan etnis. Salah satu etnis terbesar yang tinggal di Kabupaten Nunukan adalah etnis Bugis. Di sisi lain, sejarah Kota Tawau menurut Hasaan, Otham, \& Omar (2008) dan Sintang (2007) dalam Lenggono (2012) menyebutkan bahwa Kota Tawau didirikan oleh orang Bugis Wajo yang juga mempunyai usaha perdagangan di sepanjang pantai timur Kalimantan, dengan $70 \%$ orang Sabah adalah warga negara Indonesia yang beretnis Bugis.

Masyarakat Bugis yang tinggal di Tawau rata-rata sudah berpindah kewarganegaraan. Kuatnya jaringan etnis ini membuat beberapa warga Kabupaten Nunukan mempunyai kartu identitas dua negara, yaitu Kartu Tanda Penduduk (KTP) Indonesia dan Identity Card (IC) Malaysia (Ghafur, 2016). Kepemilikan kartu identitas ganda pada umumnya digunakan untuk keberlangsungan usaha yang sudah dibangun pada berbagai sektor. Jaringan identitas etnis menjadi bagian strategi dari masyarakat Nunukan untuk mempertahankan kestabilan dengan memperoleh pekerjaan, terpenuhinya kebutuhan hidup, pelayanan kesehatan, fasilitas pendidikan, dan mitra dagang (Rudiatin, 2018). Jaringan tersebut juga terbentuk karena mobilitas masyarakat Pulau Sebatik keturunan Bugis yang mempunyai kedudukan di Tawau (Alihar, 2018).

\section{PERILAKU MASYARAKAT PESISIR DI PERBATASAN NUNUKAN - TAWAU}

Hubungan masyarakat sektor kelautan dan perikanan dengan lingkungan kelautan dan perikanan merupakan bentuk dari kegiatan sosial ekonomi masyarakat untuk pemenuhan kebutuhan hidup dan keberlangsungan usaha perikanan. Hubungan tersebut diwujudkan masyarakat pesisir perbatasan yang mempunyai interaksi sosial ekonomi unik dalam bentuk perilaku terhadap potensi perikanan, tenaga kerja, pasar, teknologi, modal, dan tabungan.

\section{Perilaku Masyarakat terhadap Sumber Daya Perikanan}

Pelaku utama kelautan dan perikanan Kabupaten Nunukan memperoleh manfaat sumber daya perikanan mayoritas melalui usaha perikanan tangkap dan perikanan budi daya rumput laut. Jumlah rumah tangga perikanan (RTP) tangkap yang mengakses sumber daya perikanan mencapai 2.117 dan RTP budi daya sebanyak 2.718 (Badan Pusat Statistik Kabupaten Nunukan, 2018). Nelayan dan pembudi daya rumput laut dalam memanfaatkan potensi perikanan melalui beberapa cara seperti diperoleh secara turun menurun dari orang tua, kerja sama dengan masyarakat lokal, serta melalui pemerintah daerah dan pemerintah pusat (Gambar 1).

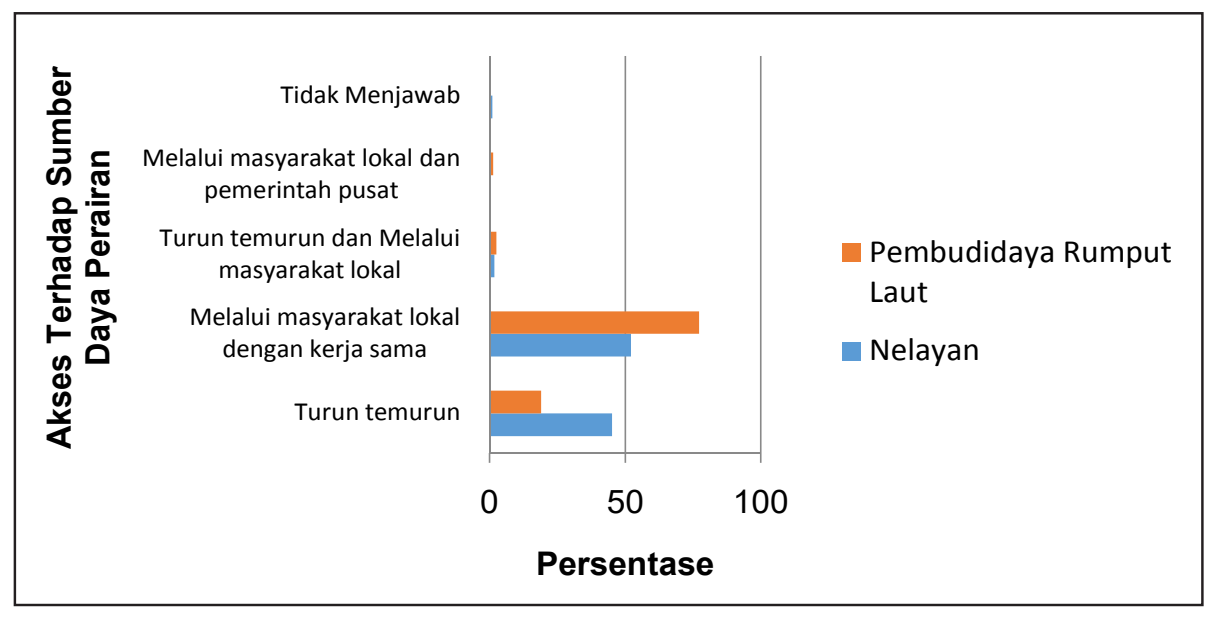

Gambar 1. Sebaran Akses Responden Terhadap Sumber Daya Perairan

Sumber: Data primer diolah, 2020 
Gambar 1, memberi informasi perilaku akses responden nelayan dan pembudi daya terhadap potensi sumber daya. Secara umum, akses terhadap sumber daya diperoleh secara turun-temurun dan melalui kerja sama dengan masyarakat lokal.

Pemanfaatan sumber daya perikanan oleh nelayan, $52 \%$ diperoleh melalui kerja sama dengan masyarakat lokal dan $45 \%$ secara turun-temurun. Kerja sama dengan masyarakat lokal dalam usaha penangkapan ikan dilakukan nelayan dengan pedagang ikan untuk mendapat modal membeli kebutuhan operasional melaut. Nelayan mempunyai kewajiban mematuhi aturan usaha perikanan tangkap agar usaha perikanan tersebut terkendali dan memberi manfaat pada semua pihak. Kewajiban tersebut tertuang dalam Peraturan Menteri Kelautan dan Perikanan Republik Indonesia Nomor 5/PERMEN-KP/2019 tentang Perubahan Atas Peraturan Menteri Kelautan dan Perikanan Nomor 23/PERMEN-KP/2013 Tentang Pendaftaran dan Penandaan Kapal Perikanan.

Pada peraturan tersebut, nelayan dengan kapal di bawah 10 GT tidak diwajibkan untuk membuat izin namun tetap mendaftarkan armadanya ke dinas perikanan kabupaten atau kota. Kapal perikanan di atas 10 GT - 30 GT wajib dilengkapi dengan SIUP, SIPI, dan SIKPI yang dikeluarkan oleh gubernur, sedangkan kapal perikanan di atas $30 \mathrm{GT}$ harus dilengkapi perizinan SIUP, SIPI, dan SIKPI yang diterbitkan oleh Direktur Jenderal Perikanan Tangkap. Peraturan tersebut secara langsung akan mengendalikan akses $84 \%$ responden nelayan yang memanfaatkan sumber daya perikanan melakukan penangkapan dan bertransaksi menjual ikan segar ke Tawau.

Perairan Nunukan juga digunakan sebagai lahan budi daya rumput laut. Pada aktivitas perairan, $19 \%$ responden pembudi daya mendapatkan akses pemanfaatan lokasi budi daya dari orang tua dan $77 \%$ responden melalui kerja sama dengan masyarakat lokal (Gambar 1). Pembudi daya dibatasi zona perikanan budi daya, seperti tertuang dalam Peraturan Daerah Provinsi Kalimantan Utara Nomor 4 Tahun 2018 tentang Rencana Zonasi Wilayah Pesisir dan Pulau-Pulau Kecil Provinsi Kalimantan Utara Tahun 2018 2038. Zonasi perikanan budi daya diperlukan karena perkembangan usaha yang pesat dan dapat menimbulkan potensi konflik dengan pengguna lahan pesisir lainnya, seperti penangkapan ikan, jalur tranportasi, dan kegiatan wisata (Saleh, 2015).
Zonasi tersebut sangat diperlukan karena aktivitas perekonomian sebagian masyarakat perikanan Kabupaten Nunukan bergantung dari budi daya rumput laut, dan budi daya ini dinilai mampu berperan dalam pengentasan kemiskinan (Wijaya \& Sari, 2008). Rumput laut di lokasi kajian dapat dibudidayakan hampir sepanjang tahun dan mampu berproduksi hingga 3.000 ton kering/bulan (Radiarta, Erliana, Haryadi, \& Rosdiana, 2016). Permintaan komoditas rumput laut yang tinggi menyebabkan pembudi daya hanya memanfaatkan hasil produksi dalam bentuk mentah. Faktor kebutuhan ekonomi menjadi alasan pembudi daya untuk menjual rumput laut dalam bentuk kering dan bukan dalam bentuk olahan.

\section{Perilaku Masyarakat terhadap Tenaga Kerja}

Tenaga kerja merupakan salah satu fungsi produksi dalam usaha perikanan. Pelaku usaha perikanan di Kabupaten Nunukan mempunyai beberapa kriteria dalam penentuan tenaga kerja. Kriteria tersebut berdasarkan lokasi tempat tinggal dan sistem kekerabatan. Gambar 2 menunjukkan faktor kesukuan atau etnis masih mendominasi penentuan tenaga kerja dalam usaha perikanan di Kabupaten Nunukan. Pelaku usaha perikanan Kabupaten Sebatik sebagian besar berasal dari suku Bugis (Sulawesi Selatan). Dengan demikian, tenaga kerja yang dipilih oleh nelayan mayoritas berasal dari etnis Bugis, baik dari keluarga maupun kerabat yang berada dalam 1 (satu) kabupaten atau luar kabupaten. Berbeda halnya dengan tenaga kerja pada usaha rumput laut, kriteria penentuan tenaga kerja adalah penduduk setempat tanpa melihat suku. Namun demikian, mayoritas penduduk Kabupaten Nunukan beretnis Bugis maka tenaga kerja yang digunakan adalah penduduk lokal dengan etnis Bugis. Relasi sosial yang terjalin antara pemilik usaha dan tenaga kerja beretnis Bugis di perantauan atau dengan keluarga di kampung halaman dijelaskan oleh Saleh (2015) sebagai bentuk modal sosial dalam mengendalikan sumber ekonomi, sebagai ajang pertukaran informasi kegiatan bisnis sekaligus untuk menjaga ikatan emosional.

Preferensi utama memilih tenaga kerja pada Gambar 2 adalah berdasarkan penduduk setempat tanpa melihat suku, kerabat satu suku dan penduduk setempat dari suku tertentu. Walaupun terdapat $21 \%$ nelayan dan $22 \%$ pembudi daya tidak menjawab. Di Nunukan, 22\% nelayan dan $43 \%$ pembudi daya rumput laut yang menggunakan penduduk setempat tanpa melihat suku. Pada 


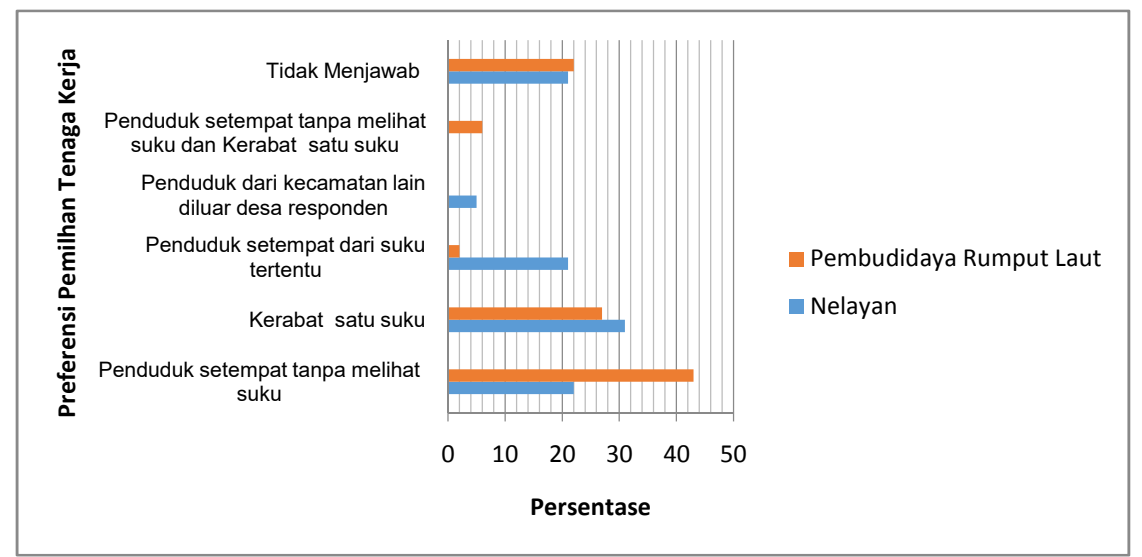

Gambar 2. Sebaran Preferensi Responden dalam Pemilihan Tenaga Kerja Perikanan.

Sumber: Data primer diolah, 2020

sisi lain, terdapat $31 \%$ nelayan dan $27 \%$ pembudi daya rumput laut menggunakan tenaga kerja dari kerabat satu suku, $21 \%$ nelayan dan $2 \%$ pembudi daya rumput laut menggunakan penduduk setempat dari suku tertentu. Relasi penggunaan tenaga kerja yang demikian diperkirakan untuk keberlangsungan usaha dan mendapat kepercayaan dari pekerja.

Aksesibilitas untuk mendapatkan tenaga kerja yang sesuai dengan kriteria pemilik usaha dapat dilakukan melalui pihak ketiga (perantara) atau pemilik mencari tenaga kerja sendiri. Pihak ketiga yang dimaksud adalah orang yang menjadi penghubung untuk mencarikan tenaga kerja seperti melalui pekerja yang telah bekerja pada pemilik, kerabat dari desa asal tenaga kerja atau melalui sesama pelaku usaha. Hubungan kerja yang terbentuk, menimbulkan hak dan kewajiban antara pemilik dengan pekerja. Pekerja pada usaha perikanan tangkap dan budi daya rumput bekerja tanpa target dan batas waktu, sementara itu pemilik memberikan hak berupa upah kepada pekerja. Mayoritas pekerja pada perikanan tangkap mendapatkan upah dengan bagi hasil, sedangkan pekerja pada budi daya rumput laut mendapatkan upah dan bonus.

Nelayan yang mendapat upah dengan bagi hasil adalah nelayan musiman yang melaut lebih dari satu hari yang menggunakan mesin tempel dengan alat tangkap jaring dan mempunyai anak buah kapal (Nurisnaeny, 2016). Upah tenaga kerja pada pembudi daya rumput laut umumnya diberikan untuk membayar kegiatan pembuatan pondasi, pemasangan bibit rumput laut, pemanenan rumput laut, pelepasan rumput laut, pembersihan tali ris, dan pengeringan rumput laut. Menurut Wijaya \&
Sari (2018), upah pekerja dalam budi daya rumput laut per bulan berkisar antara Rp1.500.000,00 sampai dengan Rp2.500.000,00 per bulan.

\section{Perilaku Masyarakat terhadap Potensi Pasar}

Pasar menjadi tempat bertemunya penjual dan pembeli untuk melakukan transaksi. Pasar produk perikanan Kabupaten Nunukan mayoritas bukan untuk dikonsumi lokal dalam kabupaten, melainkan dipasarkan ke luar kabupaten dan ke negara lain (Gambar 3). Pasar terbesar nelayan Kabupaten Nunukan adalah Tawau. Sebanyak 89\% responden menjual ikan hasil tangkapannya ke Negara Bagian Sabah Malaysia tersebut dan $11 \%$ untuk konsumsi lokal. Produk rumput laut $100 \%$ dipasarkan ke luar Nunukan, yaitu Surabaya dan Makassar.

Pangsa pasar produk perikanan bagi mayoritas nelayan dan pembudi daya biasanya mencari pasar sendiri dan bekerja sama dengan pedagang pengumpul, baik dengan perjanjian maupun tanpa perjanjian. Dasar dari kerja sama tanpa perjanjian di antara pelaku usaha adalah kepercayaan (trust). Kepercayaan diperlukan untuk membangun jaringan sosial pemasaran (Amiruddin, 2014). Ditambahkan oleh Prasetiyo et al. (2016), dengan kepercayaan dapat juga membuka peluang penggunaan modal bersama.

Nelayan dan pembudi daya yang telah bekerja sama dengan pedagang pengumpul mempunyai kewajiban untuk mensuplai ikan hasil tangkapan dan rumput laut sesuai kemampuan kapasitas produksi pelaku usaha perikanan. Hasil produksi nelayan terserap oleh pasar terutama Pasar Tawau dengan berbagai kualitas dan 


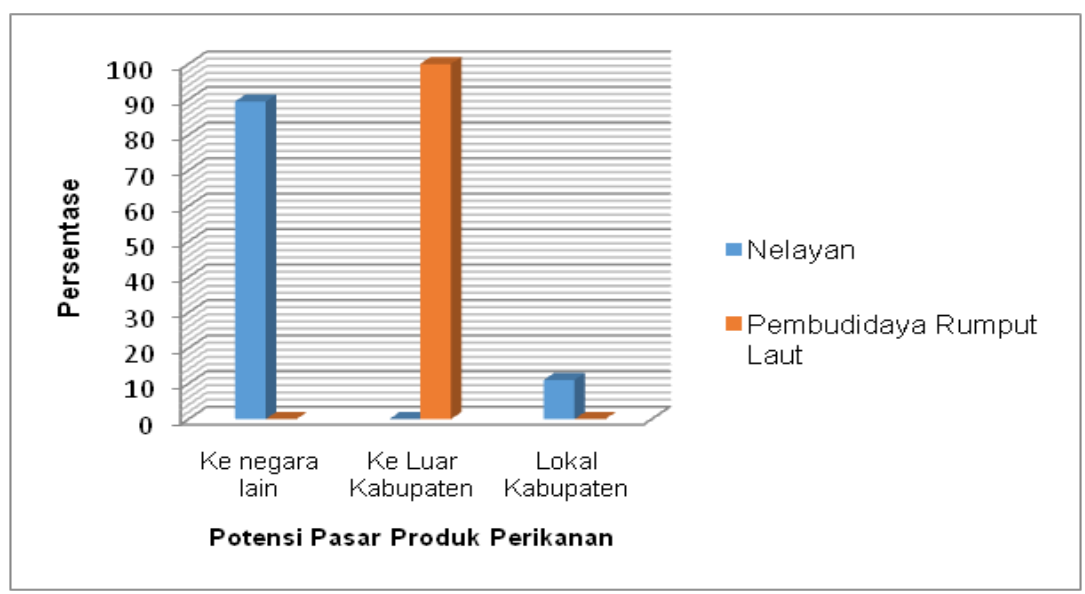

Gambar 3. Sebaran Potensi Pasar Perikanan Responden.

Sumber: Data primer diolah, 2020

ukuran. Harga jual yang tinggi menjadi alasan utama nelayan menjual ikan hasil tangkapan ke Tawau. Komoditas ikan yang dipasarkan dalam bentuk segar, seperti ikan demersal, udang, dan bandeng. Ditegaskan oleh Made, Amiluddin, \& Khumaera (2013), ikan yang diperdagangkan dari Sebatik, di antaranya ikan bawal, ikan tenggiri, ikan murai (ose), ikan ote, dan ikan teri. Perdagangan ikan ke Tawau melalui mekanisme perdagangan tradisional lintas batas, tanpa Surat Keterangan Asal (SKA) barang dan Angka Pengenal Ekspor (APE). Para pedagang ikan Kabupaten Nunukan mempunyai agen di Sabah, yaitu perusahaan perikanan yang bertindak sebagai penjamin.

Terkait dengan produk rumput laut, pasar Surabaya dan Makassar mampu menyerap hasil rumput laut dengan berbagai kualitas dengan harga menyesuaikan kualitas produk rumput laut. Radiarta et al. (2016) menjelaskan, pembudi daya menjual rumput dalam bentuk kering dengan kadar air maksimum 30\%. Sistem pembayaran yang diterima oleh nelayan setiap minggu; setelah ikan diterima oleh pedagang dan setelah ikan laku terjual. Berbeda dengan pembudi daya rumput laut yang menyatakan menerima pembayaran setelah barang diterima oleh pedagang.

\section{Perilaku Masyarakat terhadap Teknologi}

Teknologi perikanan untuk kegiatan usaha perikanan diperoleh responden melalui beberapa sumber, yaitu turun-temurun, penyuluh perikanan dan pemberi modal, serta mencari sendiri dari sumbernya. Gambar 4 menjelaskan, sebanyak $23 \%$ nelayan memperoleh teknologi perikanan dari orang tua dan $28 \%$ dari petugas penyuluh perikanan. Selain itu, $11 \%$ nelayan sumber teknologi penangkapan ikan berasal dari pemilik modal, namun terdapat $19 \%$ responden nelayan yang mencari sendiri teknologi dari sumbernya. Pada budi daya rumput laut, $35 \%$ sumber informasi teknologi rumput laut di Nunukan adalah dari penyuluh perikanan.

Teknologi perikanan dari penyuluh perikanan diperoleh melalui program bantuan dengan ukuran kapal lebih dari 10 GT. Adat kebiasan nelayan Kabupaten Nunukan adalah menggunakan perahu di bawah 5 GT dengan satu hari operasi penangkapan dan dilakukan secara perseorangan. Dengan armada lebih dari 10 GT menjadi teknologi baru bagi nelayan karena memerlukan anak buah kapal (ABK) dalam menjalankan usaha dengan alat tangkap jaring milenium.

Pembudi daya rumput laut mendapatkan teknologi budi daya mayoritas mencari sendiri dan dari petugas penyuluh perikanan. Pembudi daya mengadopsi teknologi budi daya rumput dari pembudi daya yang telah berhasil melakukan budi daya rumput laut. Nelayan dalam mengakses teknologi perikanan, $60 \%$ responden menyatakan tidak mempunyai kewajiban untuk melaporkan terkait dengan pemanfaatan teknologi yang digunakan. Hanya 19\% responden yang menyebutkan diwajibkan memberikan laporan tentang teknologi yang digunakan.

Sementara itu, pembudi daya $(37 \%)$ berkewajiban untuk memberikan informasi terkait dengan teknologi budi daya yang digunakan, $15 \%$ responden menjawab tidak mempunyai kewajiban melaporkan, serta $23 \%$ memberikan dua pernyataaan bahwa tidak ada kewajiban dan diwajibkan memberikan laporan pemanfaatan teknologi. Pelaku utama yang tidak melaporkan pemanfaatan teknologi adalah nelayan dan 


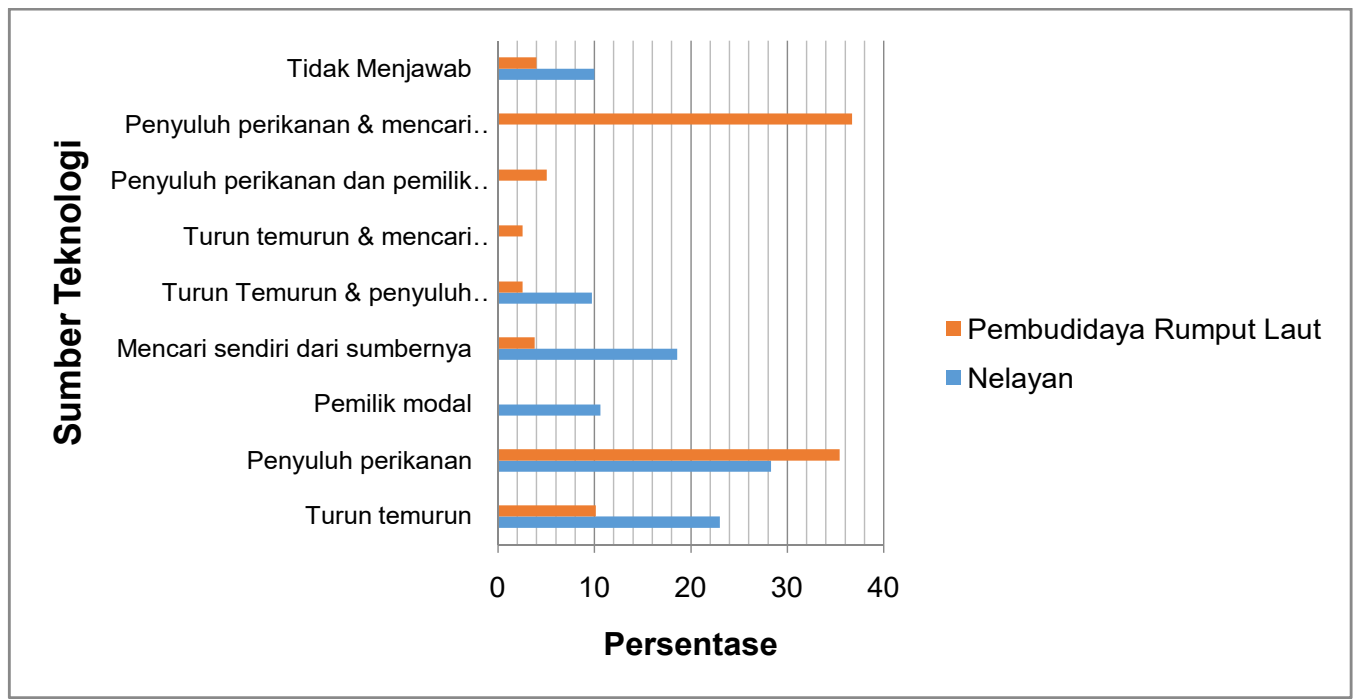

Gambar 4. Sebaran Sumber Teknologi Responden.

Sumber: Data primer diolah, 2020

pembudi daya yang tidak mendapatkan program bantuan baik dari pemerintah maupun lembaga non pemerintah.

Beberapa pelaku usaha yang mempunyai kewajiban untuk melaporkan kondisi teknologi adalah nelayan dan pembudi daya rumput laut yang mendapatkan program berbantuan pemerintah, seperti kapal, alat penangkapan ikan, lantai jemur rumput laut, tali untuk budi daya rumput laut (tali pondasi, tali angkar, dan tali ris). Bantuan pemerintah diberikan salah satunya kepada kelompok masyarakat berbadan hukum berupa bantuan operasional, sarana, dan prasarana.

Sesuai dengan Peraturan Menteri Kelautan dan Perikanan Republik Indonesia Nomor 60/ PERMEN-KP/2017 tentang Perubahan Atas Peraturan Menteri Kelautan dan Perikanan Nomor 70/PERMEN-KP/2016 Tentang Pedoman Umum Dalam Rangka Penyaluran Bantuan Pemerintah di Kementerian Kelautan dan Perikanan bahwa penerima bantuan pemerintah diwajibkan memberikan laporan perkembangan pelaksanaan pemberian bantuan. Laporan ini sebagai sarana untuk memberikan umpan balik terhadap program berbantuan yang telah diberikan terkait dengan kesesuaian teknologi. Selain itu, nelayan dan pembudi daya mendapatkan hak pelatihan terhadap teknologi yang diintroduksikan dalam program berbantuan. Di samping itu, masih ditemukan juga penerima bantuan rumput laut yang tidak melapor karena terdapat persepsi bahwa bantuan bukan merupakan modal untuk berusaha (Bank Indonesia Kantor Perwakilan Provinsi Kalimantan Timur, 2013).

\section{Perilaku Masyarakat terhadap Sumber Permodalan}

Permodalan menjadi komponen penting sebelum memulai suatu usaha. Sumber permodalan usaha pada nelayan dan pembudi daya rumput di Kabupaten Nunukan dapat dipelajari pada Gambar 5. Sebanyak $40 \%$ nelayan memperoleh modal dari pedagang pengumpul. Nelayan menjadi nelayan binaan dari pedagang pengumpul ikan dan mempunyai kewajiban untuk menjual ikan hasil tangkapan ke pemilik modal. Hal tersebut juga ditegaskan Solihin, Wisudo, Haluan, \& Martianto (2011) bahwa para nelayan mempunyai ikatan modal dengan pemilik modal.

Sistem patron client berlaku dalam hubungan antar pelaku usaha perikanan di lokasi kajian. Modal usaha yang diberikan pedagang pengumpul kepada nelayan digunakan untuk membeli kebutuhan operasional, seperti bahan bakar minyak dan es. Nelayan yang telah diberikan modal diwajibkan menjual hasil tangkapannya ke pemberi modal. Pedagang pengumpul hasil perikanan Nunukan juga diperoleh dari tauke Tawau. Hal senada juga diungkapkan oleh Siburian (2012) bahwa pedagang ikan di Sebatik memperoleh modal dari pengusaha di Tawau. Ikatan dalam perdagangan ini digunakan oleh pelaku usaha perikanan untuk mengembangkan jaringan pemasaran ikan, udang (basah dan kering), serta teri. Kondisi tersebut di atas, mengindikasikan peran lembaga pembiayaan formal belum berjalan optimal dalam usaha perikanan (Setiawan et al., 2011). 


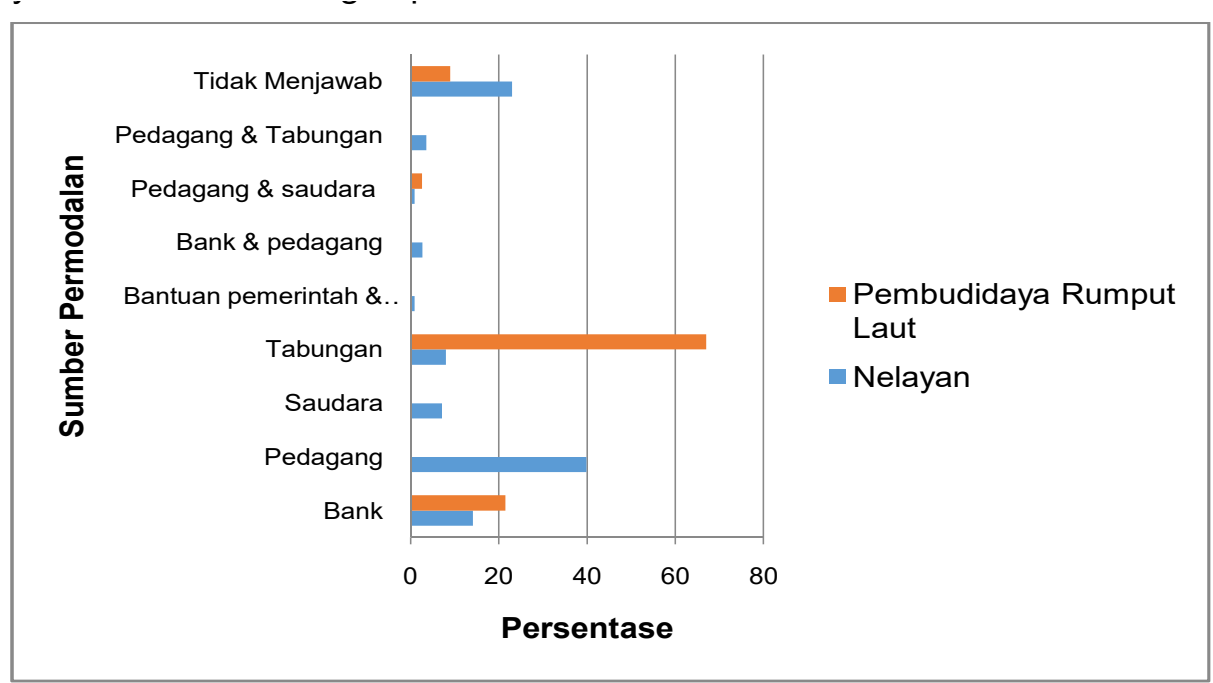

Gambar 5. Sebaran Sumber Permodalan Responden.

Sumber: Data primer diolah, 2020

Di sisi lain, permodalan untuk pembudi daya rumput $67 \%$ berasal dari modal sendiri, yaitu tabungan. Modal usaha pembudi daya diperoleh dari hasil kerja sebagai Tenaga Kerja Indonesia di Malaysia. Sejak pemberlakukan moratorium TKI, responden menyebutkan para pekerja kembali ke Indonesia dan sebagian beralih bekerja pada usaha rumput laut.

\section{Perilaku Masyarakat terhadap Tabungan}

Tabungan dapat menjadi salah satu sumber modal usaha dan sebagai salah satu bentuk investasi bagi pelaku usaha perikanan. Gambar 6 menunjukkan nelayan dan pembudi daya rumput laut, masing-masing $72 \%$ responden menyatakan menabung dalam bentuk uang. Literasi keuangan pada masyarakat kelautan dan perikanan di Kabupaten Nunukan $>70 \%$ telah memanfaatkan bank sebagai tempat untuk berinvestasi atau menabung. Alasan responden adalah menyimpan uang di bank lebih praktis, lebih terjamin, dan mudah diambil saat diperlukan.

Kabupaten Nunukan, khususnya Sebatik yang merupakan kawasan perbatasan, mempunyai keunikan dalam penggunaan mata uang, yaitu rupiah dan ringgit. Transaksi perdagangan, untuk usaha perikanan tangkap dan budi daya, menggunakan mata uang ringgit. Pada

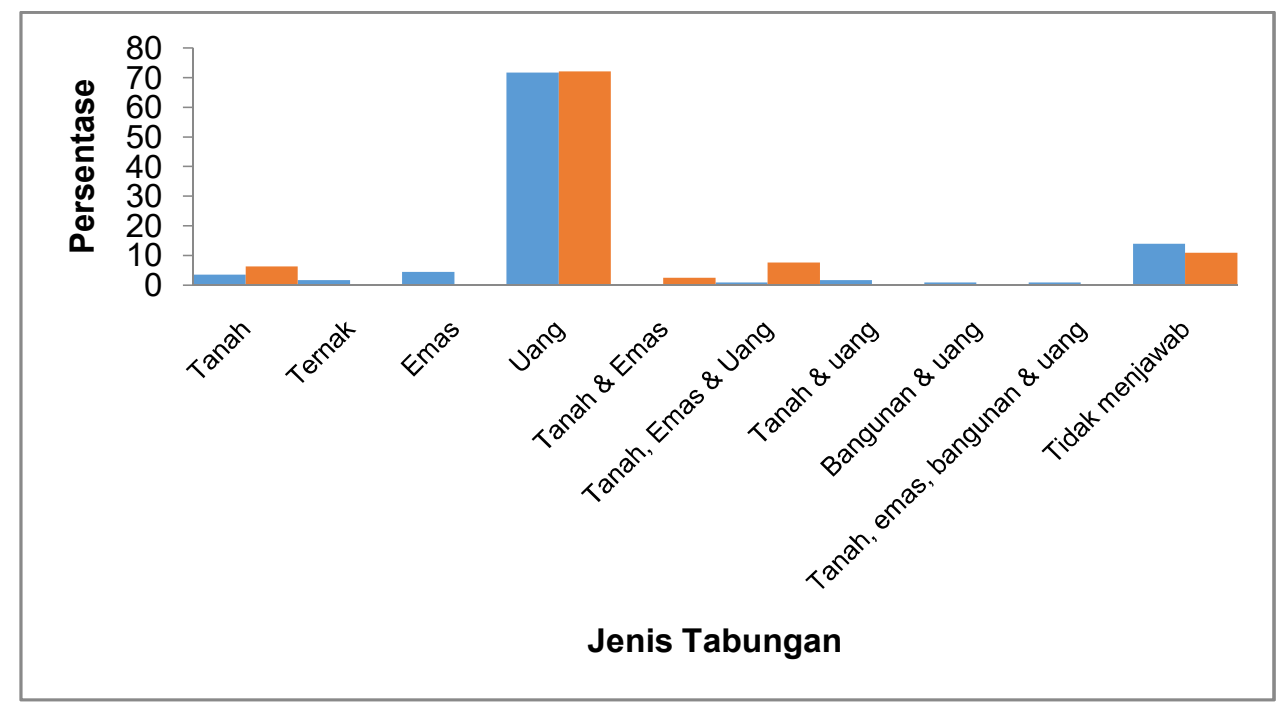

Gambar 6. Sebaran Tabungan Responden.

Sumber: Data primer diolah, 2020 
pembayaran hasil produksi perikanan, pedagang akan diberikan ringgit secara tunai. Nilai tukar mata uang ringgit yang lebih tinggi memberikan keuntungan yang kemudian ditabungkan oleh pelaku utama perikanan. Hal ini juga terjadi daerah perbatasan lainnya, seperti di Badau, Kalimantan Barat, hasil bekerja di Malaysia digunakan untuk kebutuhan salah satunya tabungan di Credit Union dan BPD (Prasojo, 2013). Perbankan di Kabupaten Nunukan telah tersebar sampai dengan wilayah yang berbatasan dengan Malaysia. Perbankan yang dapat diakses oleh masyarakat kelautan dan perikanan adalah Bank Negara Indonesia (BNI), Bank Mandiri, Bank Rakyat Indonesia (BRI), dan Bank Kaltara. Selain itu, munculnya agen-agen dari perbankan yang bekerja sama dengan nasabah perbankan mendekatkan masyarakat untuk bertransaksi perbankan secara online.

\section{PENUTUP}

Perekonomian masyarakat perbatasan di Nunukan dipengaruhi dua hal, yaitu sistem kekerabatan dalam menjalankan usaha dan perilaku bisnis yang dilaksanakan pelaku usaha. Sistem kekerabatan dibangun untuk menjamin agar usaha yang dijalankan dapat berjalan dengan baik dan terhindar dari kerugian. Oleh sebab itu, usaha penangkapan ikan dan budi daya rumput laut yang terdapat di Nunukan berkembang menurut kelompok masyarakat dengan etnis tertentu. Pada budi daya rumput laut, usaha ini dimaksudkan juga untuk menyediakan lapangan kerja bagi masyarakat yang tidak memiliki pekerjaan di desa asalnya bahkan menampung tenaga kerja indonesia yang di deportasi dari Tawau.

Perilaku bisnis yang dilakukan nelayan dan pembudi daya rumput laut adalah untuk menjamin agar usaha penangkapan ikan dan budi daya rumput laut dapat berkelanjutan serta skala usahanya dapat ditingkatkan. Upaya tersebut dilakukan dengan selektif oleh pelaku usaha melalui: akses sumber daya yang terjamin, pemilihan tenaga kerja yang tepat, memilih akses pasar yang sesuai, pemilihan teknologi yang tepat, memanfaatkan sumber modal yang saling menguntungkan, serta memanfaatkan sumber tabungan yang ada.

Oleh sebab itu, penelitian ini menyarankan pada pemerintah daerah Kabupaten Nunukan untuk membentuk asosiasi atau kelompok dagang di Nunukan berbasis etnis, agar usaha penangkapan ikan skala kecil dan budi daya rumput laut tersebut memiliki posisi tawar yang kuat dalam menjual hasil produksi di pasar tujuan. Asosiasi atau kelompok dagang tersebut dapat juga dijadikan wadah untuk menjalankan kebijakan pemerintah terkait armada tangkap serta implementasi zonasi budi daya rumput laut.

Pemerintah Kabupaten Nunukan harus mendorong lembaga keuangan finansial (terutama Bank BRI atau Bank BUMN lain) beroperasi pada desa-desa pengahasil rumput laut dan penangkapan ikan. Lembaga keuangan tersebut memberi penyuluhan/pelatihan pengelola bisnis, advokasi, dan layanan cara dan sistem transaksi perdagangan internasional dengan Tawau, serta membuka kantor kas pembantu pada lokasi-lokasi produksi untuk mengakses potensi uang yang terdapat pada desa-desa tersebut.

\section{UCAPAN TERIMA KASIH}

Terima kasih diucapkan kepada Balai Besar Riset Sosial Ekonomi Kelautan Perikanan, Badan Riset Sumber Daya Manusia Kelautan dan Perikanan yang telah membiayai kegiatan penelitian ini. Terima kasih juga diucapkan kepada Dinas Perikanan Kabupaten Nunukan, Penyuluh Perikanan Kabupaten Nunukan yang membantu dalam hal koordinasi dan bantuan di lapangan selama penelitian ini berlangsung. Kepada seluruh tim kegiatan penelitian Model Integrasi Ekonomi dalam Mendukung Percepatan Industrialisasi Perikanan Nasional di Sentra Kelautan Perikanan Terpadu (SKPT) Sebatik, Nunukan diucapkan terima kasih atas kerja samanya selama penelitian ini berlangsung.

\section{PERNYATAAN KONTRIBUSI PENULIS}

Dengan ini kami menyatakan bahwa kontribusi penulis dalam pembuatan karya tulis adalah Nensyana Shafitri sebagai kontributor utama serta Armen Zulham dan Umi Muawanah sebagai kontributor anggota. Penulis juga menyatakan bahwa telah melampirkan surat pernyataan kontribusi penulis.

\section{DAFTAR PUSTAKA}

Alihar, F. (2018). Kebijakan pengelolaan pulau-pulau terluar di tinjuau dari aspek kependudukan. Jurnal Kebijakan Sosial Ekonomi Kelautan dan Perikanan, 8(1), 39-51. doi: http://dx.doi. org/10.15578/jksekp.v8i1.6487 
Amiruddin, S. (2014). Jaringan sosial pemasaran pada komunitas nelayan tradisional Banten Jurnal Komunitas, 6(1), 106-115. doi: https://doi org/10.15294/komunitas.v6i1.2949

Badan Pusat Statistik Kabupaten Nunukan. (2018). Kabupaten Nunukan Dalam Angka 2018. Nunukan, ID: BPS Kabupaten Nunukan

Bank Indonesia Kantor Perwakilan Provinsi Kalimantan Timur. (2013). Membangun Daerah

Perbatasan dengan Rumput Laut. Samarinda, ID: Bank Indonesia KantorPerwakilan Provinsi Kalimantan Timur

Ghafur, M. F. (2016). Ketahanan sosial di perbatasan: tudi kasus Pulau Sebatik. Masyarakat Indonesia , 42(2), 233-247. doi: https://doi.org/10.14203/jmi. v42i 2.669

Kurnia, M. P. (2018). Strategi optimalisasi perdagangan lintas batas indonesia-malaysia untuk meningkatkan kesejahteraan masyarakat Pulau Sebatik Kabupaten Nunukan. Jurnal Supremasi, 7(1), 1-14. https://doi.org/10.35457/ supremasi.v7i1.372

Lenggono P. S. (2012). Jaringan Perdagangan Bugis dan Pola Penguasaan Sumber Daya Agraria di Kawasan Perbatasan Nunukan-Tawau. Workshop Pembaharuan Agraria Untuk Kesejahteraan Masyarakat Perbatasan, 85-110. Bogor, ID: D'sainku

Made, S., Amiluddin, \& Khumaera, N. I. (2013). Perdagangan Lintas Batas Produk Kelautan dan Perikanan dari Pulau Sebatik ke Tawau Malaysia. Seminar Nasional Riset dan Kebijakan Sosial Ekonomi Kelautan dan Perikanan 2013. Jakarta, ID: Balai Besar Riset Sosial Ekonomi Kelautan dan Perikanan

Nurisnaeny, P. S. (2016). Adaptasi nelayan kawasan perbatasan di Desa Sei Pancang Kecamatan Sebatik Utara Kabupaten Nunukan Provinsi Kalimantan Timur. Jurnal Communicate, 1(2), 55-65. Retrieved from https://www.neliti.com/ publications/233671/adaptasi-nelayan-kawasan-perbatasan-di-desa-sei-pancang-kecamatan-sebatik-utara

Undang - Undang Republik Indonesia Nomor 43 Tahun 2008 Tentang Wilayah Negara

Peraturan Menteri Kelautan dan Perikanan Republik Indonesia Nomor 5/PERMEN-KP/2019.

Perubahan Atas Peraturan Menteri Kelautan dan Perikanan Nomor 23 / PERM E NKP / 2013 Tentang Pendaftaran Dan Penandaan Kapal Perikanan

Peraturan Menteri Kelautan dan Perikanan Republik Indonesia Nomor 60/PERMEN-
KP/2017 tentang Perubahan Atas Peraturan Menteri Kelautan dan Perikanan Nomor 70/PERMEN-KP/2016 Tentang Pedoman Umum Dalam Rangka Penyaluran B a ntua $n$ Pemerintah Di Kementerian Kelautan Dan Perikanan

Peraturan Daerah Provinsi Kalimantan Utara Nomor 4 Tahun 2018 Tentang Rencana Zonasi Wilayah Pesisir Dan Pulau-Pulau Kecil Provinsi Kalimantan Utara Tahun 2018-2038

Prasetiyo, D. E., Zulfikar, F., Kusuma, C., Ningrum, S. A., Ferlita, T. D., \& Miyanto, A. (2016). Penguatan modal sosial sebagai upaya pengembangan ekonomi dan kapasitas rumah tangga nelayan berkelanjutan di Desa Pangandaran. OmniAkuatika, 12(1), 41-47. doi: http://dx.doi. org/10.20884/1.oa.2016.12.1.28

Prasojo, Z. H. (2013). Dinamika masyarakat lokal di perbatasan. Walisongo, 21(2), 417-436. doi: http://dx.doi.org/10.21580/ws.21.2.252

Putra, A. (2015). Hubungan kerjasama perbatasan Indonesia-Malaysia (Studi kasus perbatasan Nunukan-Tawau). Jurnal Hukum IUS QUIA IUSTUM, 2(22), 308-326. doi: https://doi. org/10.20885/iustum.vol22.iss2.art8

Radiarta, I. N., Erlania, Haryadi, J., \& Rosdiana, A. (2016). Analisa pengembangan budidaya rumput laut di Pulau Sebatik, Kabupaten Nunukan, Kalimantan Utara. Jurnal Kebijakan Perikanan Indonesia, 8(1), 29-40. doi: http://dx.doi.org/10.15578/ jkpi.8.1.2016.29-40

Raharjo, S. N., Setiawan, B., Ghafur, M. F., \& Ekawati, E. (2017). Strategi Peningkatan Kerjasama Lintas Batas (Border Crossing Agreement) Indonesia-Malaysia: Upaya Mendukung Ketahanan Sosial Masyarakat PPKT. Policy Paper. Jakarta: Pusat Penelitian Politik dan Pusat Penelitian Kependudukan LIPI. Retrieved from http://www. politik.lipi.go.id/downloadpap/Policy_Paper/ Policy \%20Paper\%20LIPI\%20tentang \% 20 BCA-BTA $\% 20$ Indonesia-Malaysia, $\% 2011 \% 20$ Des\%202017.pdf

Rudiatin, E. (2018). Malayndonesia Integrasi Ekonomi di Perbatasan Indonesia-Malaysia. Bekasi, ID: Bening Era Mandiri

Saleh, M. H. (2015). Dinamika masyarakat perbatasan: eksistensi perantau Bugis di Pulau Sebatik: Utara Perspektif Cultural Studies. Jurnal Borneo Administrator , 11(1), 31-48. doi: https://doi. org/10.24258/jba.v11i1.184

Setiawan, B., Bandiyono, S., Sudiyono, \& Soekarni, M. (2011). Kompleksitas Pembangunan dan Strategi Pemberdayaan Keluarga di Perbatasan Sebatik. Yogyakarta, ID: Elmatera 
Siburian, R. (2012). Pulau Sebatik: Kawasan Perbatasan Indonesia Beraroma Malaysia. Jurnal Masyarakat dan Budaya, 14(1), 53-75. doi : 10.14203/jmb. v14i1.87

Solihin, S., Wisudo, S. H., Haluan, J., \& Martianto, D. (2011). Pengembangan produksi perikanan tangkap di wilayah perbatasan (Kasus Kabupaten Nunukan, Kalimantan Timur). Buletin PSP, 19(2), 9-18. Diambil dari https://journal.ipb.ac.id/index. php/bulpsp/article/view/4180

Sudiar, S. (2015). Pembangunan wilayah perbatasan negara: gambaran tentang strategi pengelolaan kawasan perbatasan darat di Provinsi Kalimantan Utara. Jurnal Administrative Reform, 3(4), 489-500. doi: http://dx.doi.org/10.30872/jar. v3i4.587

Wijaya, R. A., \& Sari, Y. D. (2018). Peran usaha budidaya rumput laut dalam pengentasan kemiskinan di Pulau Nunukan. Seminar Nasional Sosial Ekonomi Kelautan dan Perikanan 2018, 451-461. Jakarta, ID: Balai Besar Riset Sosial Ekonomi Kelautan dan Perikanan

Zulham, A., Muawanah, U., Asnawi, Muhadjir, Muliawan, I., Wijaya, R. A., Shafitri, N., \& Sari, Y. D. (2018). Model Integrasi Ekonomi dalam Mendukung Percepatan Industrialisasi Perikanan di Lokasi SKPT (Nunukan). Laporan Teknis. [Tidak Dipublikasikan]. Jakarta, ID: Balai Besar Riset Sosial Ekonomi Kelautan dan Perikanan 